\title{
Bureaucracy Reform Deficit in Indonesia: A Cultural Theory Perspective
}

\author{
Arif Budy Pratama \\ Department of Public Administration, Tidar University, Indonesia \\ E-mail:kk177c@gmail.com
}

Received: July 10, 2017 Accepted: July 27, 2017 Online published: August 7, 2017

doi:10.5296/jpag.v7i3.11519 URL: https://doi.org/10.5296/jpag.v7i3.11519

\begin{abstract}
The motivation of this paper is to identify the possible unintended consequences of reform program to modernize public administration in Indonesia through cultural theory looking glass. The cultural perspective matters to understand the context of reform-based implementation and the setting of society where public sector reform occurred. Applying cultural theory perspective, four patterns of unintended consequences in Indonesia's bureaucracy reform are proposed to aid the analysis of reform deficit pattern. I name reform inertia for fatalist, formalistic reform for hierarchies, benefit-based reform for individualist, and conformity-based reform for egalitarian typed-organisations. This framework gives an alternative outlook to address potential negative effects as well as unintended consequences of bureaucracy reform in which reform advocates or public administrators could consider to anticipate in the process of reform.
\end{abstract}

Keywords: Bureaucracy, Reform, Reform Deficit, Grid-group Cultural Theory

\section{Introduction}

The greater attention on public sector reform in developing countries has emerged (Conteh \& Huque, 2014; Haque, 2013). The western-based conceptual reform in public sector especially New Public Management (NPM) and its variants are widely adopted in many developing countries to modernise their public administration. However, there is a cautious reminder for adopters, due to its ubiquities, might affects some paradoxes and incompatibilities. The ignorance of context sometimes yields some negative effects which are counter-productive on the reform program. As a developing country, Indonesia is not the exception in joining the trend of administrative reform program which simply called bureaucracy reform agenda.

Context does matter in adopting ideas of reform which mainly entrenched either in the socio-cultural area or political-jurisdiction system (Common, 2001; Massey, 2009; Vries, 


\section{Mll Macrothink}

Journal of Public Administration and Governance ISSN 2161-7104

2017, Vol. 7, No. 3

2012). However, none of the studies emphasis on systematic analysis of unintended consequences. This interpretive study attempts to zoom the intersection of the incompatibilities of reform initiatives and socio-cultural context in which the reform occurred. Thus, it aims to systematically identify the potential negative effects from bureaucracy reform agenda in Indonesia using Grid-Group Cultural Theory/GGCT (Douglas, 1982). It differentiated the social relation into four perspectives includes fatalist, hierarchy, individualist, and egalitarian way. GGCT is an anthropological approach emphasised on historical and cultural analysis which merits with the discussion of bureaucracy reform. It apprehends the way in which government institutions perceive reform from the socio-cultural standpoint.

This paper will first demonstrate the context of bureaucracy reform in Indonesia from the socio-historical point of view. Then, by adapting GGCT framework, it helps to analyse the side effect of bureaucracy reform program within real-case examples in Indonesia. Finally, it proposed the notion reform deficit as a 'dark side' of bureaucracy reform. My proposal designates into four patterns of unintended consequences in Indonesia's bureaucracy reform. They are parallels with four classifications of cultural theory approach namely reform inertia for fatalist, formalistic reform for hierarchies, benefit-based reform for individualist, and conformity-based reform for egalitarian typed-organisation.

\section{Indonesia Context}

To understand the context of bureaucracy reform, it is necessary to discuss the historical and social context of bureaucracy itself. Historical does not mean what Hood (2000) stated as 'ancestor worshippers' discussing from the commencement of modern Indonesian bureaucracy, instead at least understand where the idea of reform come from. It aims to locate appropriate analysis on bureaucracy reform to obtain precision on the contextual analysis. Thus, the chronological analysis will be beneficial on the analysis of reform.

The beginning of bureaucracy reform program initially conducted as the respond of financial crisis which surged through South East Asia mixed with political calamity and transition from new order era to reformation era. To overcome financial crisis, many developing countries adopted western model of reform originated from public choice theory (Hood, 2001), well-known as the New Public Management (NPM). The NPM approach is It also known as managerialism which mainly emphasis on management to achieve efficiency and output-based performance, professional management, performance measurement, control in output, decentralisation, competition, efficiency in resources and adopting private sector management style.

Larbi (1999) categorised Indonesia as a crisis state approach. It characterized by its serious attempts to speed up its economic recovery through decentralization, privatisation, economic deregulation, as well as the implementation of performance-based budgeting and accrual public sector accounting. Its focus on public sector finance as a core strategic reform is one of the efforts to cope with economic crisis(Harun, An, \& Kahar, 2013; Mcleod \& Harun, 2014). The enhancement on government performance especially ease of doing business, investment, business licencing, trade, customs, taxes, and other economic sectors will lead the 
acceleration of economic recovery.

After crisis period, Indonesia continues to implement bureaucracy reform program as mandated by the Long-term Development Plan 2005-2025 (Rencana Pembangunan Jangka Panjang Nasional). Before 2010, reforms were fragmented and lack of guidance provided. The institutional-based reform has started since 2008. This type-of reform only implemented in 3 pilot projects included Ministry of Finance, National Audit Board and National Supreme Court. Then, the bureaucracy reform project has expanded gradually to 75 central government institutions since 2014. As a legal foundation, Presidential Regulation Number $81 / 2010$ on Grand Design for Bureaucracy Reform was issued to conduct national bureaucratic reform which focused on the areas of organisation restructuring, regulation, governance, inspection, and human resources. All area of reform must comply to the principle of efficiency, measurable, and outcome-oriented initiative.

The post-crisis reform also influenced by managerialism approach that has similar facet to the crisis-based reform after 1998. It is signposted by the adoption of western-reform style in some reform policy documents. The reinventing government suggested by Gaebler \& Osbourne (1993) as the ambassador of US model of government reform seemed to be universal role model in managing public sector including Indonesia. Whilst, not all countries succeed implementing this imported-reform style. Context does matter to smoothly plug the reform-based adoption to the setting of society where public sector reform occurred (Common, 2001; Massey, 2009; Vries, 2012). My argument stances with the latter perspective that context and cultural aspect play an important role in public sector reform. This stance brings to the GGCT approach in analysing Indonesian bureaucracy reform.

\section{Understanding GGCT}

The main argument of GGCT is that cultural issues matters in society and people behaviour. It posits the cultural element as the centre of explaining social life. It recognises two basic scopes of sociality that have been used to identify four ideal either cultural types or rather ways of life. The two basic scopes are grid and group. Grid denotes the degree to which people behave are constrained by rules and conventions in a society. While, group represents the extent to which ones are tied to one another as part of a collective group (Douglas, 1982).

The model perceives the diversity of behaviour from preferences to behave by the rule in one hand and the collective matters in the other hand. The world is made by the influence of way of life and how people connect with their societies. "Preferences and justifications shape the world of social relations. Everything human beings do or want is culturally biased"(Mamadouh, 1999:3). 


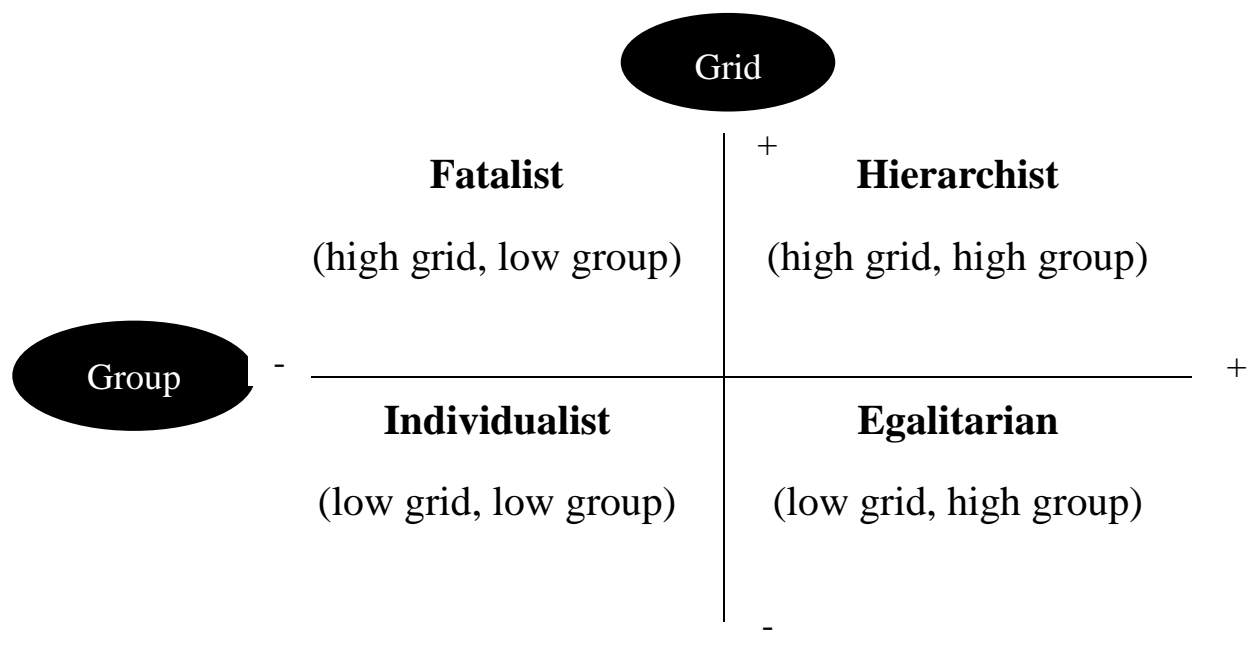

Adapted from: Hood (2000)

Figure 1. GGCT Framework

In political studies and public administration scholarships, GGCT was used by some scholars to analyse institution such as Thompson, Ellis, \& Wildavsky (1990) with the development of GGCT to analyse polity phenomena which entrenched heavily on cultural mindset. For the institutional capacities, Hendriks (1999) used the GGCT to assess learning capacities drawn from the comparative case study of interchange between car users and culture in Birmingham and Munich. The cultural facet of public institution also found in the rhetoric-based policy. A study by Smullen (2007) compares agency reform in Netherlands, Sweden, and Australia in the perspective of rhetorical cultural approach on GGCT. While, Hood (2000) scrutinised failures and weaknesses of NPM as general movement and area of study in public administration. He explained the failure and weakness of NPM in general terms. Differentiated from Hood's analysis, this paper efforts to mitigate the possible unintended consequences of bureaucracy reform specifically within Indonesian context.

Although GGCT emphasis on human preferences but its core focus is sited in organisation as the entity of social interaction. "The grid-group method starts with recognizing the exigencies of organization and not with examining ideologies, worldviews, or moral norms" (Douglas, 2012:1352). This statement strongly indicates that GGCT engrossed on broader issues of organisational analysis. Further it also can be applied in various environment and societies no matter where the societies geographically located.

The use of GGCT in analysing Indonesian bureaucracy reform is on threefold. Firstly, the study on Indonesian development or development administration from Riggs (1964) demonstrated that administration shaped by the context of society. The obvious theme in developing countries like Indonesia is what he called 'prismatic' society that are characterized by formalism, heterogeneity, and functional overlaps. The development process supported by international donors is likely failed because of insufficient ecological perspective in the implementation phase. From this lesson learned, it can be stated that cultural dimension must be considered in the study of bureaucracy reform and public 
administration.

Secondly, culture is alleged as values which drive organisation to react the various environment. "A useful theory of culture, the authors contend, should start with these questions, and the answers, given different historical conditions, should apply equally well to people of all times, places, and walks of life."(Thompson et al., 1990). In addition, culture is believed to be a driver for human behaviour. In the study of organisational culture, Schein (1996) argued that culture is basics assumption that manifest into values, behaviour and artefact. He also claimed that culture developed early in organisation and shaped as history that influenced organisation action. In Indonesia's cases, it can be seen where each institution has a unique attribute that reflect its character. For instance, the Ministry of Transport or the Ministry of Defence with semi-military exposed in their uniform or training for civil servants.

Thirdly, cultural venues must not be neglected in bureaucracy reform process as it influences the implementation of reform itself. The study of Bureaucracy Reform in the Directorate General of Tax (Wihantoro, Lowe, Cooper, \& Manochin, 2015) shows that the clash between the process of reform and cultural aspect in Indonesian government institution may reflect the inapplicability different setting used in adopted reform. It means that the reform agenda constructed by national policy and institutional operational procedure sometimes do not fit to the bureaucratic culture from the institutions. Thus, content and context of bureaucracy reform policy should be matched and synergic with organizational culture in which the reform take place.

\section{Proposing 4 Patterns of Bureaucracy Reform Deficit}

Following Thompson (1997), GGCT can be applied from small scale entities started from the individual, family, village, town, organisation to the wider scope such as a nation-state. Therefore, the analysis of bureaucracy reform can be located to national, institutional, and even individual level. It can be assumed that there will be no uniformity and high chance of diversity in real practices. In addition, as the nature of this study is exploratory, the evidence can be national, specific institution, or individual level of civil servant experiences related to bureaucracy reform.

Modified from the early model by Douglas (1982), second generation of GGCT (Thompson, 1997; Thompson et al., 1990) and cultural-rhetoric analysis from Hood (2000), the bureaucracy reform deficit can be modelled below: 


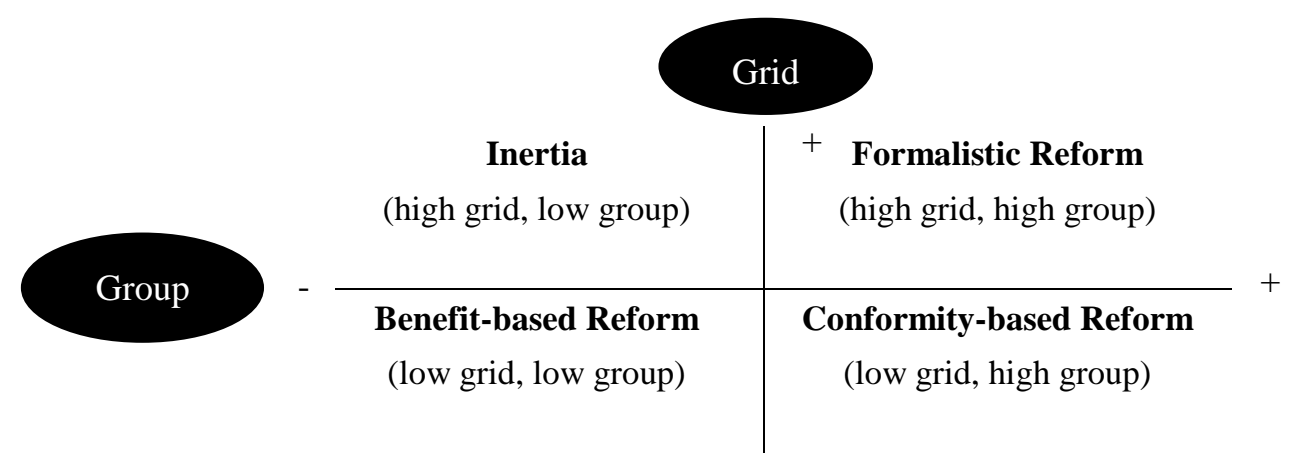

Developed by author

Figure 2. Reform Deficits Pattern

\subsection{Inertia}

The first type of pattern is named inertia. It happens in the fatalist type of institution characterised by the low degree of collectivism and high degree rule constrain in the social interaction. In bureaucracy reform context, the fatalist is apparent to be passively engaged with the idea of reform. The strong rule and low group influence will tight the civil servant to be resistance in change process. This condition is in line with the proposition that "the fatalist way of life is vulnerable to inertia"(Hood, 2000:28). Also, this this type of institution tends to be relatively slow in motion as typical of the fatalist way to be silent (Mamadouh, 1999). For Indonesian circumstances, this type can be found in the way in which some of the organisations as well as the officials reject the reform because they might think that reform will not give benefits to them. For those who have already comfortable with the status quo, apparently will reject the idea of reform. For instance, there was resistance of some head of sub-districts and structural civil servants in Jakarta Province with open bidding system in 2013. The resistance from Head of Warakas Sub-District, Jakarta Special Region, who intended to do judicial review was obvious as empirical example from reform inertia. Three years ago, this case was exposed by national media such as kompas.com, liputan6.com, and merdeka.com. This condition also likely happened for civil servants those, who will be retired soon when the reform implemented. They tend to resist the reform since it will not impact to them when they leave civil service.

\subsection{Formalistic Reform}

Unlike fatalist who has low level of grid and high level of group, hierarchist typed organisation is characterised by high level for both grid and group in the social interaction. It tends to maintain harmony and with the divided roles. Hierarchical mode emphasises on rules, regulations procedures and expertise (Hood, 2000:73-74). He also pinpointed that hierarchist vulnerable to misplaced trust in expertise and the dramatic collapse of 'big visions' (p.28). From these propositions, hierarchist institutions have tendencies that reform should have been directed from above, meaning that they prefer technocratic style of reform and too rely on expertise. The tight zip of rules and collectiveness of behaviour can imply red tape 
phenomena. Red tape simultaneously impacts more risk-averse decision culture (Bozeman \& Kingsley, 1998) that linked with stagnation.

Horhoruw et al (2009) conducted study on bureaucracy reform in Indonesia using Barber's (2007) framework on public service transformation argued that Indonesia's bureaucracy reform based on grand design agenda face problematical issues regarding with command-control approaches. It results ambiguities and complex issues of reform to attain reform outcomes. Also, the reform is alleged too 'internal' in process and could not touch directly to the public as primer stakeholders. This finding indicated that hierarchical style of reform has produced the new activities in fulfilling the requirement of bureaucracy reform and sometimes forget the main function of institutions. The fact that requirement of documentation for reform assessment to achieve remuneration is reflected the formalistic attitude toward reform. Thus, it is not surprising that many consultants for bureaucracy reform have flourished since the bureaucracy reform has been launched by national government. For instance, Constitutional Court contracted almost IDR 650 million just for 6 modules document for bureaucracy reform, National Land Agency allocated IDR 4.1 Billion for bureaucracy reform consultant, and Ministry for Energy allotted IDR 1 Billion for advisory consultant in bureaucracy reform ${ }^{1}$. These evidences brought to the discussion of formalistic way of reform which extent to written rules, regulations and procedures. Also, formalistic inclines with the deficit of reform itself and yield reform degradation towards symbolic-based reform.

\subsection{Benefit-based Reform}

Another feature is individualist type of institution that possess low grade both grid and group. Individual self-interest becomes more intense to attain self-benefit of individual. The central design of this type can be drawn from material incentive structure (Hood, 2000:104-108). The low level of control by regulation and lack of rule of law combined with a little involvement from colleagues or other entities of organisation triggered abuse of authority. (Hood, 2000:28-35) discussed this phenomenon using the terms of 'Achilles heel' which means the situation where public administration gets private gain from public office. It also can be perceived as corruption includes misappropriation, extortion, bribery, front-line abandonment, and ego-tripping. In Indonesia case, these pathologies can be found in any institutions which reflected unintended consequences from individualist types of institutions. The most appropriate example is likely in terms of remuneration or performance allowance 'tunjangan kinerja'. For those who has low in rule enforcement and in-effective collective control, the aim of reform is only for self-benefit which visibly manifested in getting remuneration. The remuneration becomes notably valued because low standard of civil service salary. The low standard of salary which caused by inadequate budget is one the factors affecting corruption (Filmer \& Lindauer, 2001; Mcleod, 2008). Indeed, allowances and or honorarium and in-kind benefits such as travel allowance have a major significant role in remunerating public sector employees (Tjiptoherijanto, 2008). The performance allowance

\footnotetext{
${ }^{1}$ http://lpse.bpn.go.id/eproc/lelang/view/238065;jsessionid=2AC91E94DAE30EBAA4F84401602EF5B9 http://www.mahkamahkonstitusi.go.id/file_lelang/Pengumuman\%20pemenang\%20RB\%202011.pdf http://eproc.esdm.go.id/eproc/lelang/view/2110109; jsessionid=FA5AEB577C3A99B15155043161DE7642
} 


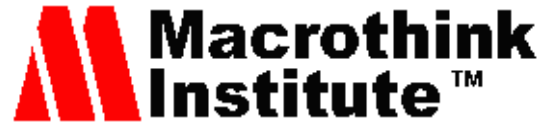

Journal of Public Administration and Governance ISSN 2161-7104 2017, Vol. 7, No. 3

turned to be ends instead of means in the reform for individualist perspective. Generally speaking, the benefit-based reform as side effect drawn from the behaviour for self-benefit implementing reform.

\subsection{Conformity-based Reform}

The last category is egalitarian institution which has high collectivism but low in obliged rules and regulation. It characterised by maintenance of solidarity that supported through intensive contact between members (Smullen, 2007:49). The low level in enforcement with high degree of communalism can deliver the bad effects in task fulfilment and day to day administration. In addition, Hood (2000:121-132) warned about their greedy of demands, vulnerable of deadlock, and in an extreme way can cause chaos. Another feature of egalitarian side-effect called 'poly communalism' that can be grasped in developing countries context. Poly communalism is defined as society interaction among communities based on suspicion and distrust (Haque, 2010:770). In Indonesia, the egalitarian way posits on the conformity of behaviour in civil servant as well as agency or institution. The strong collective behaviour encourages members to adapt and closely act as other members. Some apparent phenomena are the similarities in organisational structure among ministries and or agencies regardless their aims and functions. Also, the formula in deciding the grade of performance allowance is based on echelon as well as position, regardless of job description and job risk that showed collectivism is salient within institutions.

The 4 patterns and some examples in the real world can be summarised in the table below:

Table 1. Bureaucracy Reform Deficit: Interpretation and Sample of Behaviour

\begin{tabular}{|c|c|c|}
\hline Type of Institution & Interpretation & Example of Behaviour \\
\hline $\begin{array}{llll}\text { Inertia } & \text { (high grid, low } \\
\text { group) } & & & \end{array}$ & $\begin{array}{l}\text { Organisations as well as the } \\
\text { officials reject the reform } \\
\text { because they might think } \\
\text { that reform will not give } \\
\text { benefits to them. For those } \\
\text { who have already } \\
\text { comfortable with the status } \\
\text { quo, apparently will reject } \\
\text { the idea of reform. }\end{array}$ & $\begin{array}{l}\text { There was resistance of } \\
\text { some head of sub-districts } \\
\text { and structural civil servants } \\
\text { in Jakarta Province with } \\
\text { open bidding system in } 2013\end{array}$ \\
\hline $\begin{array}{l}\text { Formalistic Reform (high } \\
\text { grid, high group) }\end{array}$ & $\begin{array}{l}\text { Formalistic attitude towards } \\
\text { reform }\end{array}$ & $\begin{array}{l}\text { World Bank working paper } \\
\text { (2009) on Indonesian } \\
\text { bureaucracy reform argued } \\
\text { that Indonesia's bureaucracy } \\
\text { reform based on grand } \\
\text { design agenda face } \\
\text { problematical issues } \\
\text { regarding } \\
\text { command-control approach }\end{array}$ \\
\hline
\end{tabular}




\begin{tabular}{|c|c|c|}
\hline & & $\begin{array}{l}\text { with the result of } \\
\text { ambiguities to attain } \\
\text { outcomes. Also, the reform } \\
\text { is alleged too 'internal' in } \\
\text { process and could not touch } \\
\text { directly to the public due to } \\
\text { its formalistic features. }\end{array}$ \\
\hline $\begin{array}{l}\text { Benefit-based Reform (low } \\
\text { grid, low group) }\end{array}$ & $\begin{array}{l}\text { The low level of control by } \\
\text { regulation and a little } \\
\text { involvement from } \\
\text { colleagues or other entities } \\
\text { of organization triggered } \\
\text { abuse of authority }\end{array}$ & $\begin{array}{l}\text { Remuneration or } \\
\text { performance allowance } \\
\text { 'tunjangan kinerja' turned to } \\
\text { be ends instead of means in } \\
\text { the reform for individualist } \\
\text { perspective. }\end{array}$ \\
\hline $\begin{array}{l}\text { Conformity-based Reform } \\
\text { (low grid, high group) }\end{array}$ & $\begin{array}{l}\text { Conformity of behaviour in } \\
\text { civil servant as well as } \\
\text { agency or institution. The } \\
\text { strong collective behaviour } \\
\text { encourages members to } \\
\text { adapt and closely act as } \\
\text { other members. }\end{array}$ & $\begin{array}{l}\text { The similarities in } \\
\text { organisational structure } \\
\text { among ministries and or } \\
\text { agencies regardless of their } \\
\text { functions. } \\
\text { The grade in performance } \\
\text { allowance based on echelon } \\
\text { as well as position that } \\
\text { showed collectivism is } \\
\text { salient within institution. }\end{array}$ \\
\hline
\end{tabular}

\section{Conclusion and Future Research}

From the interpretive analysis above, I propose four patterns of Indonesian bureaucracy reform deficit drawn from GGCT point of view. First, the reform inertia is characterised by the existence of resistance and demotivated purposes from civil servants to bureaucracy reform program. The inertia based-reform can be found in the institutions which have strong rule and regulation and low degrees of collective among members. Second, formalistic reform might be occurred in the hierarchy-type of institutions. It is characterised by the formalistic attitude toward reform and sometimes yield ambiguous impacts on formalistic and administrative output. Third, the individualist institutions that have low grades both grid and group attributes might be fashioned with benefit-based reform. This type sometimes generates abuse authorities to the civil servant self-benefit. Fourth, the egalitarian type tends to practise conformity-based reform as a side effect of low in rule constrain and high collectivism.

This paper contributes to both theoretical and practical venues in public administration scholarship. Theoretically, the unintended consequences of bureaucracy reform are rarely 
discussed comprehensively. The typology model on reform deficit may offers systematic framework to analyse bureaucracy reform studies. Practically, policy makers can mitigate unintended consequences as well as negative effects that may occur while the process of reform undergo. Thus, they can employ the bureaucracy reform deficit model to develop strategies and anticipation policies to tackle the 'dark side' of bureaucracy reform.

Future research may improve deeper understanding in the cultural theory perspective on bureaucracy reform by conducting a case study approach that emphasis on specific occasion. This may enhance the depth of analysis and the relation of culture and civil service behaviour. In addition, empirical studies to test four patterns of reform deficits are immersed to be conducted to enrich the body of knowledge on the administrative reform scholarship.

\section{References}

Barber, M. (2007). Instruction to Deliver: Fighting to Transform Britain's Public Services. London: Methuen.

Bozeman, B., \& Kingsley, G. (1998). Risk culture in public and private organizations. Public Administration Review, 52(2), 109-118.

Common, R. (2001). Public management and policy transfer in Southeast Asia, (October), v, 273 .

Conteh, C., \& Huque, A. S. (2014). Public Sector Reform in Developing Countries, Paradox and Practices. New York: Roudledge.

Douglas, M. (1982). Introduction to Grid/Group Analysis." Essays In The Sociology Of Perception. (M. Douglas, Ed.). London: Roudledge.

Douglas, M. (2012). Being Fair to Hierarchists Author ( s ): Mary Douglas Reviewed work ( s ): Source : University of Pennsylvania Law Review, Vol . 151, No . 4 ( Apr ., 2003 ), pp . 1349-1370 Published by: The University of Pennsylvania Law Review Stable URL: http://www, 151(4), 1349-1370.

Filmer, D., \& Lindauer, D. L. (2001). Does Indonesia Have a "Low Pay" Civil Service? Bulletin of Indonesian Economic Studies, 37(2), 189-205. http://doi.org/10.1080/00074910152390883

Gaebler, T., \& Osbourne, G. (1993). Reinventing Government: How the Entrepreneurial Spirit is Transforming the Public Sector. New York: Plume Book.

Haque, M. S. (2013). Globalization, State Formation, and Reinvention in Public Governance: Exploring the Linkages and Patterns in Southeast Asia. Public Organization Review, 13(4), 381-396. http://doi.org/10.1007/s11115-013-0258-3

Harun, H., An, Y., \& Kahar, A. (2013). Implementation and challenges of introducing NPM and accrual accounting in Indonesian local government. Public Money \& Management, 33(5), 383-388. http://doi.org/10.1080/09540962.2013.817131

Hendriks, F. (1999). Political Institutions and Public Policy: A Tale of Two Cities. London: 
Edward Elgar Publisihing.

Hood, C. (2000). The Art of the State: Culture, Rhetoric and Public Management. Oxford: Clarendon Press.

Hood, C. (2001). A PUBLIC MANAGEMENT FOR ALL SEASONS? Public Administration, 69(1). http://doi.org/10.1111/j.1467-9299.1991.tb00779.x

Horhoruw, M., Karippacheri, T., Sutiyono, W., \& Thomas, T. (2009). Transforming The Public Sector in Indonesia: Delivering Total Reformasi. Indonesia. Retrieved from http://siteresources.worldbank.org/EXTGOVANTICORR/Resources/3035863-128942874633 7/Transforming_Public_Sector_Indonesia.pdf

Larbi, G. (1999). The New Public Management Approach in Crisis State (No. 112).

Mamadouh, V. (1999). Grid-group Cultural Theory: an Introduction. Geo Journal, 47(3), 395-409.

Massey, A. (2009). Policy mimesis in the context of global governance. Policy Studies, 30(3), 383-395. http://doi.org/10.1080/01442870902888940

Mcleod, R. H. (2008). Inadequate budgets and salaries as instruments for institutionalizing public sector corruption in Indonesia. South East Asia Research, 199-223. http://doi.org/10.5367/000000008785260464

Mcleod, R. H., \& Harun, H. (2014). Public Sector Accounting Reform at Local Government Level in Indonesia. Financial Accountability \& Management, 30(May), 238-258. Retrieved from http://onlinelibrary.wiley.com/doi/10.1111/faam.12035/full

Riggs, F. (1964). Administration in Developing Countries: The Theory of Prismatic Society. Boston: Houghton Mifflin Co.

Schein. (1996). Culture: The Missing Concept in Organization Studies. Administrative Science Quarterly, 41(2), 229-240.

Shamsul Haque, M. (2010). Rethinking development administration and remembering Fred W. Riggs. International Review of Administrative Sciences, 76(4), 767-773. http://doi.org/10.1177/0020852310394320

Smullen, A. (2007). Translating agency reform. Rhetoric and culture in comparative perspective. Public Management. http://doi.org/10.1057/9780230289703

Thompson, M. (1997). Cultural Theory and integrated assessment. Environmental Modeling and Assesment, 3(2), 139-150.

Thompson, M., Ellis, R., \& Wildavsky, A. (1990). Cultural Theory. Boulder: Westview Press.

Tjiptoherijanto, P. (2008). Civil Service Reform in Indonesia. Comparative Governance Reform in Asia: Democracy, Corruption, and Government Trust, 8(2), 39-54. http://doi.org/10.1016/S0732-1317(08)17004-X 


\section{Macrothink}

Journal of Public Administration and Governance ISSN 2161-7104 2017, Vol. 7, No. 3

Vries, M. De. (2012). Public sector reform: an overview of recent literature and research on NPM and alternative paths. International Journal of Public Sector Management, 26(1), 4-16. http://doi.org/10.1108/09513551311293408

Wihantoro, Y., Lowe, A., Cooper, S., \& Manochin, M. (2015). Bureaucratic reform in post-Asian Crisis Indonesia: The Directorate General of Tax. Critical Perspectives on Accounting, 31, 44-63. http://doi.org/10.1016/j.cpa.2015.04.002

\section{Copyright Disclaimer}

Copyright for this article is retained by the author(s), with first publication rights granted to the journal.

This is an open-access article distributed under the terms and conditions of the Creative Commons Attribution license (http://creativecommons.org/licenses/by/4.0/). 